\title{
A Case of Pyogenic Liver Abscess Infected with Fusobacterium necrophorum Depicted by Microscopy and Confirmed by Tissue Culture
}

\author{
Yuichi Nozawa ${ }^{1}$, Satoru Joshita ${ }^{1}$, Mana Fukushima ${ }^{2}$, Yukiko Sugiyama ${ }^{3}$, Yuki Ichikawa ${ }^{1}$, \\ Takefumi Kimura ${ }^{1}$, Susumu Morita ${ }^{1}$, Atsushi Kamijo ${ }^{1}$, Takeji Umemura ${ }^{1}$, Tetsuya Ichijo ${ }^{1}$, \\ Akihiro Matsumoto ${ }^{1}$, Kaname Yoshizawa ${ }^{1}$ and Eiji Tanaka ${ }^{1}$
}

\begin{abstract}
A 40-year-old man was admitted with a continuous high grade fever accompanying a relatively large solitary liver abscess with septations. A puncture of the abscess revealed gram-negative rods that could be identified histologically as Fusobacterium necrophorum, which was later confirmed by tissue culture. The patient was switched to meropenem and penicillin, and cured of the infection. Fusobacterium necrophorum is a rare bacterium causing potentially fatal liver abscesses in humans. Clinicians should bear Fusobacterium necrophorum in mind when treating patients with an enlarged solitary liver abscess.
\end{abstract}

Key words: liver abscess, Fusobacterium necrophorum, gram-negative rod

(Intern Med 50: 1815-1819, 2011)

(DOI: 10.2169/internalmedicine.50.5147)

\section{Introduction}

Pyogenic liver abscesses are the most common type of visceral abscess, with an estimated annual incidence of 2.3 cases per 100,000 population (1). The median age of onset is just less than 60 years $(2,3)$ and men are more susceptible than women (1). Abscesses typically occur when pyogenic bacteria enter the liver via the portal circulation or the biliary tract from an intra-abdominal infection, or by hematogenous spread from a systemic infection (2). As for clinical symptoms, fever is seen in $89.6 \%$ of cases, right upper quadrant pain in $72.2 \%$, and chills in $69.0 \%$ (4). Risk factors for pyogenic liver abscess are diabetes mellitus (5), hepatobilliary or pancreatic disease (6), and liver transplantation (1), although such abscesses can occur in the absence of any underlying medical conditions. The major sources of pyogenic liver abscess have been reported to be the Klebsiella species, Escherichia coli, and the Enterococcus species (4). The mortality rate of pyogenic liver abscess has de- creased substantially, ranging from 2 to 12 percent, and is related more to comorbidities than the abscess itself $(4,6,7)$. Still, it is important to diagnose this disease as early as possible and promptly begin therapy, which includes administration of appropriate antibiotics and percutaneous abscess drainage.

Fusobacterium necrophorum is a nonmotile, gramnegative anaerobe that normally inhabits the pharynx, gastrointestinal tract, female genital organs, and urinary tract $(8,9)$. It is clinically relevant for humans because it is a major contributor to Lemierre's syndrome $(9,10)$. Fusobacterium necrophorum infection is seen predominantly in males between the ages of 16 to 23 years and most commonly in the months of January to March, the latter for unknown exact reasons (11). Although Fusobacterium necrophorum is often the etiologic bacterium in liver abscesses in livestock such as cattle (12), there have been very few cases found in humans.

Herein, we report a patient presenting with a single, relatively large liver abscess infected with Fusobacterium necro-

\footnotetext{
${ }^{1}$ Department of Medicine, Division of Gastroenterology and Hepatology, Shinshu University School of Medicine, Japan, ${ }^{2}$ Department of Laboratory Medicine, Shinshu University Hospital, Japan and ${ }^{3}$ Department of Radiology, Shinshu University School of Medicine, Japan Received for publication January 13, 2011; Accepted for publication May 10, 2011 Correspondence to Dr. Satoru Joshita, joshita@ shinshu-u.ac.jp
} 
Table 1. Laboratory Findings on Admission

\begin{tabular}{lcllrl}
\hline Blood & & & Chemistry / Serology & \\
\hline WBC & 5,900 & $/ \mu \mathrm{L}$ & TP & 7.6 & $\mathrm{~g} / \mathrm{dL}$ \\
Seg & 50 & $\%$ & Alb & 3.5 & $\mathrm{~g} / \mathrm{dL}$ \\
Band & 24 & $\%$ & AST & 11 & $\mathrm{IU} / \mathrm{L}$ \\
Mono & 6 & $\%$ & ALT & 12 & $\mathrm{IU} / \mathrm{L}$ \\
Eos & 1 & $\%$ & T-Bil & 0.76 & $\mathrm{mg} / \mathrm{dL}$ \\
Bas & 0 & $\%$ & GGT & 96 & $\mathrm{IU} / \mathrm{L}$ \\
Lym & 18 & $\%$ & ALP & 239 & $\mathrm{IU} / \mathrm{L}$ \\
RBC & 339 & $\times 10^{4} / \mu \mathrm{L}$ & CRP & 7.46 & $\mathrm{mg} / \mathrm{dL}$ \\
$\mathrm{Hb}$ & 13.0 & $\mathrm{~g} / \mathrm{dL}$ & Glu & 116 & $\mathrm{mg} / \mathrm{dL}$ \\
$\mathrm{Ht}$ & 32.1 & $\%$ & HbAlc & 5.7 & $\%$ \\
Plt & 52.0 & $\times 10^{4} / \mu \mathrm{L}$ & HBsAg & 0.1 & $\mathrm{C} \cdot \mathrm{O} \cdot \mathrm{I}$ \\
& & & HCVAb & 0.1 & $\mathrm{C} \cdot \mathrm{O} \cdot \mathrm{I}$ \\
& & & Tumor markers & & \\
\cline { 2 - 5 } & & & AFP & 1.2 & $\mathrm{ng} / \mathrm{mL}$ \\
& & & PIVKA-II & 7 & $\mathrm{mAU} / \mathrm{mL}$ \\
& & CEA & 1.4 & $\mathrm{ng} / \mathrm{mL}$ \\
& & CA19-9 & 10.7 & $\mathrm{U} / \mathrm{mL}$ \\
\hline
\end{tabular}

phorum that was diagnosed histologically, confirmed by cell culture, and ultimately cured.

\section{Case Report}

A 40-year-old man was admitted to our hospital in the month of January suffering from continuous high grade fever that had been nonresponsive to oral clarithromycin 400 $\mathrm{mg} /$ day for 5 days followed by moxifloxacin $400 \mathrm{mg} /$ day for 12 days. A nodular lesion in the liver was detected by ultrasonography (US) by his primary physician. Two years prior, the patient commenced treatment for hypertension with olmesartan $20 \mathrm{mg} /$ day orally and diabetes mellitus type 2 with subcutaneous insulin therapy four times daily, both with satisfactory results. The patient was an archeological excavator of 10 years and had never been abroad. He consumed approximately $40 \mathrm{~g}$ ethanol daily and was heterosexual. No diseases were noted among his immediate family members.

On examination, the patient was $165 \mathrm{~cm}$ tall, weighed 57 $\mathrm{kg}$, and had a body mass index of $20.9 \mathrm{~kg} / \mathrm{m}^{2}$. His body temperature was $38.3^{\circ} \mathrm{C}$. He had a remittent fever, but appeared well with no signs of anemia or jaundice in his conjunctiva and presented no abdominal masses or hepatosplenomegaly. He showed no signs of acute sore throat with purulent exudates, cervical or submandibular lymphoadenopathy, or tenderness indicating thrombophlebitis of the internal jugular vein, although he had earlier lost several teeth due to dental caries. Neurological, chest, and abdominal physical examinations revealed no abnormal findings. Laboratory tests on admission (Table 1) revealed a shift to the left of white blood cells and inflammatory reaction. The patient had favorable glucose control. A chest X-ray revealed no abnormal shadows.

A relatively large abscess was noted in the posterior segment of the right lobe of the liver by US, which appeared as a homogeneous low echoic cavity with septations surround- ing a ring-like low echoic lesion $70 \times 65 \mathrm{~mm}$ in diameter (Fig. 1a). A computed tomography (CT) showed a heterogeneous low density area accompanied with septations within the posterior segments of the liver (Fig. 1b), whose surrounding area was slightly enhanced in contrast-enhanced CT (Fig. 1c). The patient was intravenously administered sulbactam/cefoperazone (SBT/CPZ) $6 \mathrm{~g} /$ day on admission as an empiric therapy. Antibodies against ameba in both serum and feces were negative, as were blood cultures taken several times for bacteria and fungi. The man received an abscess content fluid puncture and a liver abscess tissue biopsy on hospital day 5 for histological examination. Histopathological findings of the abscess fluid smear uncovered filamentous and slightly curved rods after careful examination (Fig. 2a). Liver parenchyma surrounding the abscess showed considerable inflammatory cell infiltration that included neutrophils and lymphocytes (Fig. 2b). Confirmation of Fusobacterium necrophorum from tissue culture incubation was obtained on day 11 , and the patient was switched to intravenous meropenem (MEPM) $2 \mathrm{~g} / \mathrm{day}$ according to antibiotic susceptibility. Ultrasonography 7 days later revealed that the size of abscess had been reduced to $35 \times 35$ $\mathrm{mm}$ diameter with virtually no lumen. Fever and clinical symptoms disappeared, indicating that the MEPM was effective. The patient was switched to sawacillin orally $750 \mathrm{~g} / \mathrm{day}$ on day 20 . He was discharged on day 23 , and sawacillin was discontinued 8 weeks later because the patient showed no signs of relapse, such as fever, abdominal pain, or chills, and based on evidence of abscess disappearance by nonenhanced CT (Fig. 1d) and US (data not shown). His clinical course is shown in Fig. 3.

\section{Discussion}

Unlike its incidence in livestock, liver abscess infected with Fusobacterium necrophorum is extremely rare in humans. All known previous reports are summarized in Ta- 


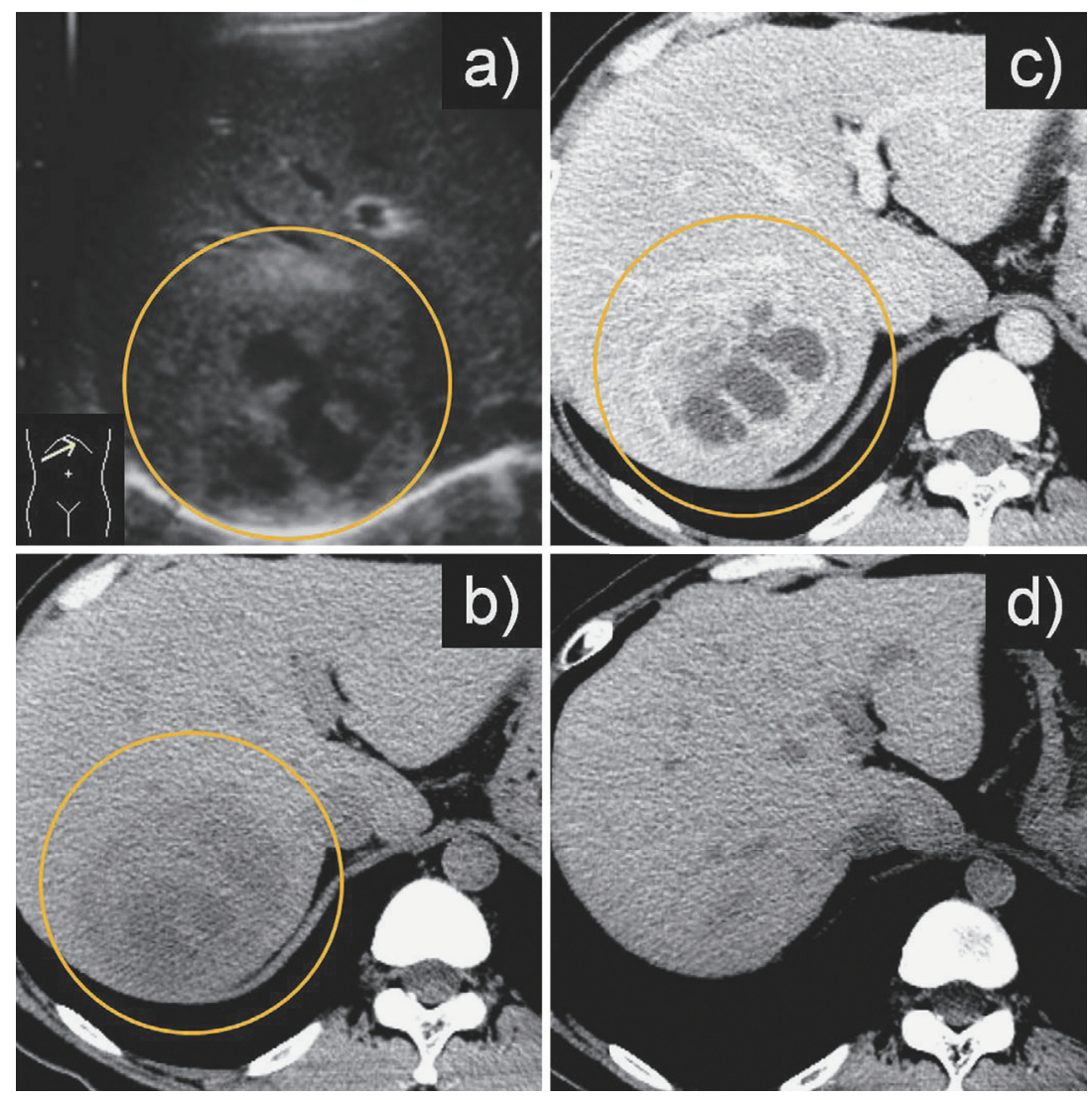

Figure 1. a) Single liver abscess showing a homogeneous low echoic cavity with septations surrounding a ring-like low echoic lesion $70 \times 65 \mathrm{~mm}$ in diameter by ultrasonography at the posterior segment of the right lobe of the liver (yellow circle). b) A non-enhanced computed tomography (CT) scan shows a heterogeneous low density area accompanied with septations within the posterior segments of the liver (yellow circle). c) The lesion is enhanced in a late phase contrast-enhanced CT accompanied with a slightly ring-like enhanced region (yellow circle). d) A non-enhanced CT shows the disappearance of the abscess lesion at the posterior segment of the right lobe of the liver after antibiotic therapies 8 weeks after discharge.

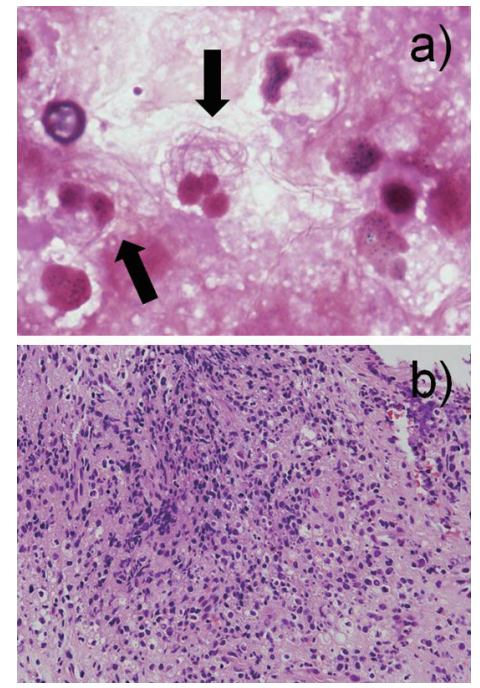

Figure 2. a) Filamentous and slightly curved rods (black arrows) being phagocytized by neutrophils are shown by tissue cytology with Gram staining. b) Liver parenchyma surrounding the abscess is infiltrated with inflammatory cells, including neutrophils and lymphocytes in Hematoxylin and Eosin staining. ble 2 (13-25). Liver abscesses in cattle from Fusobacterium necrophorum are considered to be secondary to the primary focus of infection on the ruminal wall through the portal circulation $(12,26,27)$. In humans, the route of liver abscess development is obscure and speculatively different among cases. Here, infiltration into the liver via the portal circulation from diverticula in the colon (25) or hematogenous spread from dental caries $(21,26)$ may have been the source of infection in the present patient. It could be also considered that risk factors included his controlled diabetes mellitus or moderate alcohol consumption.

An early diagnosis and prompt therapy are needed for liver abscesses infected with Fusobacterium necrophorum since potentially lethal cases with liver abscesses exist $(4,7)$ It was also reported that an abscess size of greater than 5 $\mathrm{cm}$ in diameter as in the present case was a significant prognostic factor for mortality (28). Here, a definitive diagnosis of bacterial infection was made via tissue cytology and histology and later confirmed by culture, but our suspicion of an etiologic bacterium also contributed to the diagnosis. It is typically considered that microscopic findings alone are sufficient for identification of Fusobacterium necrophorum. 
Table 2. Published Cases of Liver Abscesses Infected from Fusobacterium necrophorum

\begin{tabular}{|c|c|c|c|c|c|c|c|}
\hline Case & $\begin{array}{l}\text { Age } \\
\text { (yrs) }\end{array}$ & Gender & Clinical symptoms & Baseline conditions & Therapies & Duration & Result \\
\hline $1(13)$ & $8 \mathrm{~m}$ & M & freve & N.P. & $\begin{array}{c}\text { drainage } \\
\text { AMPC, GM, metronidazole }\end{array}$ & 3 weeks & cured \\
\hline $2(14)$ & 17 & $\mathrm{~F}$ & $\begin{array}{c}\text { fever } \\
\text { abdominal pain }\end{array}$ & N.P. & metronidazole & 6 weeks & cured \\
\hline $3(15)$ & 19 & $\mathrm{~F}$ & $\begin{array}{c}\text { fever } \\
\text { abdominal pain }\end{array}$ & N.P. & $\begin{array}{c}\text { drainage } \\
\text { PCG, CTRX, metronidazole }\end{array}$ & 6.5 weeks & cured \\
\hline $4(16)$ & 21 & M & $\begin{array}{c}\text { fever } \\
\text { abdominal pain }\end{array}$ & peritonsillar abscess & $\begin{array}{c}\text { drainage } \\
\text { TAZ/PIPC, metronidazole }\end{array}$ & over 6 weeks & cured \\
\hline $5(17)$ & 22 & M & freve & N.P. & GM, CTRX, metronidazole & 6 weeks & cured \\
\hline $6(18)$ & 25 & M & fever, chills & dental caries & drainage, AMPC/CVA & 3 weeks & cured \\
\hline 7 (19) & 27 & M & $\begin{array}{l}\text { fever, abdominal pain } \\
\text { general malaise, }\end{array}$ & N.P. & $\begin{array}{c}\text { drainage } \\
\text { AMPC, metronidazole }\end{array}$ & 8 weeks & cured \\
\hline $8(20)$ & 31 & M & $\begin{array}{c}\text { fever } \\
\text { general malaise }\end{array}$ & N.P. & drainage, metronidazole & 5 weeks & cured \\
\hline $9(21)$ & 36 & M & fever & dental caries & drainage, CTRX, AMPC & not described & cured \\
\hline $10(22)$ & 44 & M & $\begin{array}{c}\text { fever, chills } \\
\text { general malaise }\end{array}$ & N.P. & drainage, CTRX & 3 weeks & cured \\
\hline $12(23)$ & 51 & $\mathrm{~F}$ & $\begin{array}{l}\text { fever, general malaise } \\
\text { abdominal pain }\end{array}$ & N.P. & MEPM, drainage & 3 weeks & cured \\
\hline $11(24)$ & 64 & M & fever, chills & allergy to penicillin & CPFX, metronidazole & 2 weeks & cured \\
\hline $12(25)$ & 71 & M & $\begin{array}{l}\text { general malaise } \\
\text { weight loss }\end{array}$ & $\begin{array}{l}\text { diabetes mellitus } \\
\text { diverticulum }\end{array}$ & PCG, AMPC & 12 weeks & cured \\
\hline Our case & 40 & M & fever & $\begin{array}{l}\text { diabetes mellitus } \\
\text { dental caries, diverticulum }\end{array}$ & MEPM, AMPC & 8 weeks & cured \\
\hline
\end{tabular}

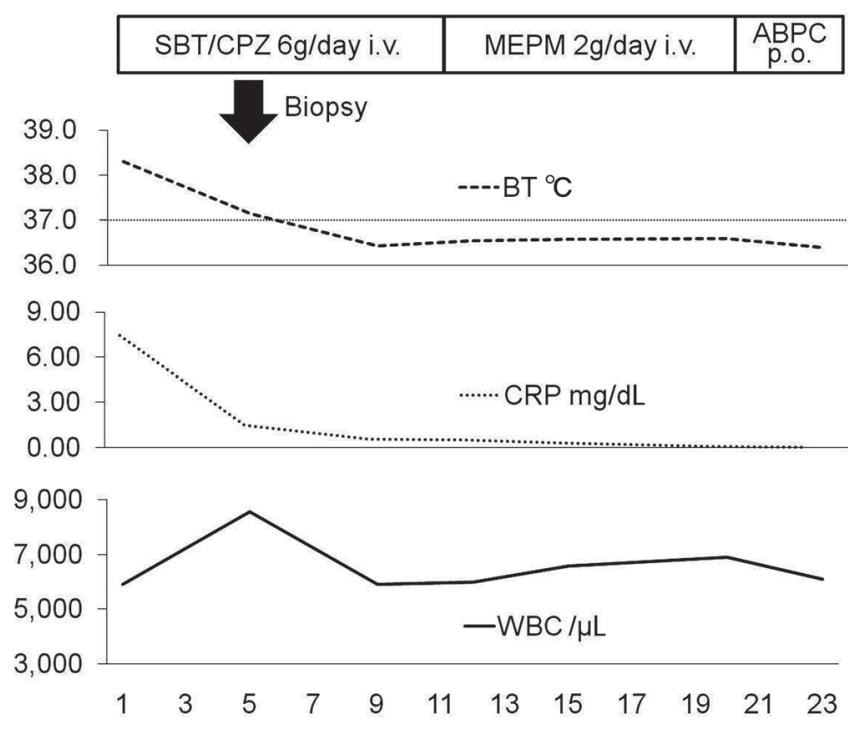

Figure 3. Clinical course of this patient.

Our diagnosis was validated by a positive tissue culture result 6 days after a liver puncture.

It has also been reported that most isolates from patients infected with Fusobacterium necrophorum are responsive to metronidazole, but $2 \%$ are resistant to penicillin and $15 \%$ to erythromycin (11). Similar to earlier cases $(13-20,22,24,25)$, the present patient responded to treatment with ampicillin. Pyogenic liver abscesses usually require specific antibiotic therapies with or without drainage, except for cases complicated with an amoebic abscess (29). Following hospital discharge, antibiotic therapy should be continued for four to six weeks (30) as reported previously $(13-20,22,24,25)$, although there have been no randomized controlled trials evaluating the optimal treatment duration. Patients showing a good response to initial drainage should be treated with two to four weeks of parenteral therapy, while patients with incomplete drainage should receive four to six weeks of parenteral therapy (Table 1). The remainder of the treatment course may then be completed with oral therapy tailored to culture results $(7,31)$.

In conclusion, clinicians should bear in mind that patients who present with a solitary large liver abscess may be infected with Fusobacterium necrophorum and should undergo a histological examination to ensure prompt identification and treatment.

\section{The authors state that they have no Conflict of Interest (COI).}

\section{Acknowledgement}

We thank Trevor Ralph for his English editorial assistance.

\section{References}

1. Kaplan GG, Gregson DB, Laupland KB. Population-based study of the epidemiology of and the risk factors for pyogenic liver abscess. Clin Gastroenterol Hepatol 2: 1032-1038, 2004. 
2. Mohsen AH, Green ST, Read RC, McKendrick MW. Liver abscess in adults: ten years experience in a UK centre. QJM 95: 797-802, 2002.

3. Chan KS, Chen CM, Cheng KC, Hou CC, Lin HJ, Yu WL. Pyogenic liver abscess: a retrospective analysis of 107 patients during a 3-year period. Jpn J Infect Dis 58: 366-368, 2005.

4. Rahimian J, Wilson T, Oram V, Holzman RS. Pyogenic liver abscess: recent trends in etiology and mortality. Clin Infect Dis 39: 1654-1659, 2004.

5. Thomsen RW, Jepsen P, Sorensen HT. Diabetes mellitus and pyogenic liver abscess: risk and prognosis. Clin Infect Dis 44: 11941201, 2007.

6. Chuang HC, Chen TL, Chiang DH, et al. Clinical and bacteriological characteristics of pyogenic liver abscess in non-diabetic patients. J Microbiol Immunol Infect 42: 385-392, 2009.

7. Yu SC, Ho SS, Lau WY, et al. Treatment of pyogenic liver abscess: prospective randomized comparison of catheter drainage and needle aspiration. Hepatology 39: 932-938, 2004.

8. Bennett KW, Eley A. Fusobacteria: new taxonomy and related diseases. J Med Microbiol 39: 246-254, 1993.

9. Brazier JS. Human infections with Fusobacterium necrophorum. Anaerobe 12: 165-172, 2006.

10. Riordan T. Human infection with Fusobacterium necrophorum (Necrobacillosis), with a focus on Lemierre's syndrome. Clin Microbiol Rev 20: 622-659, 2007.

11. Brazier JS, Hall V, Yusuf E, Duerden BI. Fusobacterium necrophorum infections in England and Wales 1990-2000. J Med Microbiol 51: 269-272, 2002

12. Tadepalli S, Narayanan SK, Stewart GC, Chengappa MM, Nagaraja TG. Fusobacterium necrophorum: a ruminal bacterium that invades liver to cause abscesses in cattle. Anaerobe 15: 36-43, 2009.

13. Embree JE, Williams T, Law BJ. Hepatic abscesses in a child caused by Fusobacterium necrophorum. Pediatr Infect Dis J 7: 359-360, 1988.

14. Stallworth JR, Carroll JM. Lemierre's syndrome: new insights into an old disease. Clin Pediatr (Phila) 36: 715-717, 1997.

15. Clarke MG, Kennedy NJ, Kennedy K. Serious consequences of a sore throat. Ann R Coll Surg Engl 85: 242-244, 2003.

16. David H. A 21-year-old man with fever and abdominal pain after recent peritonsillar abscess drainage. Am J Emerg Med 27: e513e514, e515, 2009.

17. Thatcher P. Hepatic abscesses caused by Fusobacterium necrophorum as part of the Lemierre syndrome. J Clin Gastroenterol 37: 196-197, 2003.
18. Lei WY, Chang WH, Shih SC, Liu CJ, Shih CH. Pyogenic liver abscess with Prevotella species and Fusobacterium necrophorum as causative pathogens in an immunocompetent patient. J Formos Med Assoc 108: 253-257, 2009.

19. Hagelskjaer L, Pedersen G. Fusobacterium necrophorum septicemia complicated by liver abscess. A case report. APMIS 101: 904906, 1993.

20. Weed TE, Merritt CR, Bowen JC. Surgical management of multiple hepatic abscesses using ultrasonography for sequential evaluation. South Med J 75: 1270-1273, 1982.

21. Yoneda M, Kato S, Mawatari H, et al. Liver abscess caused by periodontal bacterial infection with Fusobacterium necrophorum. Hepatol Res 41: 194-196, 2011.

22. Hwang JJ, Lau YJ, Hu BS, Shi ZY, Lin YH. Haemophilus parainfluenzae and Fusobacterium necrophorum liver abscess: a case report. J Microbiol Immunol Infect 35: 65-67, 2002.

23. Ishiguro $\mathrm{T}$, Takayanagi $\mathrm{T}$, Ikarashi $\mathrm{H}$. A case of intrapelvic tumor accompanying multiple liver abscesses. Nihon Sanhujinka Gakkai Niigata Chihoubukai Kaishi 102: 8-10, 2009.

24. Ergas D, Abdul-Hai A, Sthoeger Z, Menahem BH, Miller R. Multiple pyogenic liver abscesses following hemorrhoid banding. Isr Med Assoc J 9: 753-754, 2007.

25. Athavale NV, Leitch DG, Cowling P. Liver abscesses due to Fusobacterium spp that mimick malignant metastatic liver disease. Eur J Clin Microbiol Infect Dis 21: 884-886, 2002.

26. Takeuchi S, Nakajima Y, Ueda H, Motoi Y, Kobayashi Y, Morozumi T. Hepatic abscess formation in cattle inoculated with Fusobacterium necrophorum. Nippon Juigaku Zasshi 46: 339344, 1984.

27. Langworth BF. Fusobacterium necrophorum: its characteristics and role as an animal pathogen. Bacteriol Rev 41: 373-390, 1977.

28. Yang CC, Yen CH, Ho MW, Wang JH. Comparison of pyogenic liver abscess caused by non-Klebsiella pneumoniae and Klebsiella pneumoniae. J Microbiol Immunol Infect 37: 176-184, 2004.

29. Chavez-Tapia NC, Hernandez-Calleros J, Tellez-Avila FI, Torre A, Uribe M. Image-guided percutaneous procedure plus metronidazole versus metronidazole alone for uncomplicated amoebic liver abscess. Cochrane Database Syst Rev CD004886, 2009.

30. Chen YW, Chen YS, Lee SS, et al. A pilot study of oral fleroxacin once daily compared with conventional therapy in patients with pyogenic liver abscess. J Microbiol Immunol Infect 35: 179-183, 2002.

31. Zerem E, Hadzic A. Sonographically guided percutaneous catheter drainage versus needle aspiration in the management of pyogenic liver abscess. AJR Am J Roentgenol 189: W138-W142, 2007.

(C) 2011 The Japanese Society of Internal Medicine http://www.naika.or.jp/imindex.html 